Article

\title{
Synthesis, Crystal Structure, Photoluminescence Properties and Antibacterial Activity of a Zn(II) Coordination Polymer Based on a Paddle-Wheel Cluster
}

\author{
Qingguo Meng ${ }^{1}$, Lintong Wang ${ }^{1}$, Dongfang Wang ${ }^{2}$, Jianjian Yang ${ }^{1}$, Chen Yue ${ }^{1}$ and Jitao Lu ${ }^{1, *}$ \\ 1 College of Chemical Engineering and Environmental Chemistry, Weifang University, \\ Weifang 261061, China; mengqg@wfu.edu.cn (Q.M.); wanglt6408@163.com (L.W.); \\ yangjianjian9@163.com (J.Y.); wfuyuechen@163.com (C.Y.) \\ 2 College of Bioengineering, Weifang University, Weifang 261061, China; wangdf@wfu.edu.cn \\ * Correspondence: lujitao@foxmail.com
}

Academic Editor: Shujun Zhang

Received: 15 March 2017; Accepted: 13 April 2017; Published: 17 April 2017

\begin{abstract}
A binuclear $\mathrm{Zn}(\mathrm{II})$ complex of formula $\left\{\left[\mathrm{Zn}(\mathrm{BCPPO}) \mathrm{H}_{2} \mathrm{O}\right] \cdot 3 \mathrm{C}_{2} \mathrm{H}_{5} \mathrm{OH}\right\}_{n}(\mathbf{1})\left[\mathrm{H}_{2} \mathrm{BCPPO}=\right.$ Bis 4-carboxyphenyl phenyl phosphine oxide] has been synthesized and structurally characterized by single crystal X-ray diffraction, Powder X-ray diffraction (PXRD), Thermogravimetric analysis (TG), Elemental analysis (EA) and Infrared spectroscopy (IR). As revealed by the single crystal X-ray diffraction, in the binuclear $\mathrm{Zn}$ (II) complex, two paddle-wheel-type $\mathrm{Zn}_{2}$ units were connected by four BCPPO ligands to form one-dimensional chains. Their antibacterial activity was evaluated by using a minimal bactericidal concentration (MBC) benchmark. The binuclear Zn(II) complex shows excellent and long-term antibacterial activity against Escherichia coli and Staphylococcus aureus. In addition, the Photoluminescence properties of the binuclear $\mathrm{Zn}(\mathrm{II})$ complex was also investigated.
\end{abstract}

Keywords: Bis 4-carboxyphenyl phenyl phosphine oxide; coordination polymers; antibacterial activity; photoluminescence properties

\section{Introduction}

In recent years, coordination polymers (CPs), which are assembled by metal ions/clusters and organic ligands, have attracted considerable attention owing to their fascinating structural topologies and potential applications in gas storage, separation, drug delivery, chemical absorption, luminescence, electronics, catalysis and their biological activity [1-10]. In particular, the luminescent coordination polymers have become an active topic of investigation due to the various applications in chemical sensors, photochemistry and electroluminescent display [11-14]. General $\mathrm{d}^{10}$ transition metal are particularly remarkable candidates in the construction of photoluminescence materials because the metal is hard to oxidize or reduce [15-17].

In the past decades, plenty of people have suffered from diseases caused by unsafe drinking water and food containing bacteria such as Escherichia coli, Staphylococcus aureus and Bacillus subtilis. The traditional low molecular weight antibacterial materials have many disadvantages, such as toxicity to the environment and short-term antibacterial activity. Hence, there is an urgent need for the development of effective antibacterial materials. Among chemical disinfectants, metal/metal oxide nanoparticulate systems, as well as coordination polymers (CPs), have attracted increasing attention because CPs can be easy recycled to minimize the environmental problems and CPs with high surface area show more active sites resulting in excellent antibacterial activity [18-21]. 
With the above issues in mind, in order to design and synthesize coordination polymers and explore the potential application in photochemistry and antibacterial, in the present work, a binuclear $\mathrm{Zn}(\mathrm{II})$ complex of formula $\left\{\left[\mathrm{Zn}(\mathrm{BCPPO}) \mathrm{H}_{2} \mathrm{O}\right] \cdot 3 \mathrm{C}_{2} \mathrm{H}_{5} \mathrm{OH}\right\}_{\mathrm{n}}(\mathbf{1})[\mathrm{BCPPO}=$ Bis 4-carboxyphenyl phenyl phosphine oxide] has been synthesized and structurally characterized by single crystal X-ray diffraction; powder X-ray diffraction (PXRD), Figure S1; Elemental analysis (EA) and Infrared Spectroscopy (IR), Figure S2; thermogravimetric analysis (TG), Figure S3. The complex 1 shows excellent and long-term antibacterial activity against Escherichia coli and Staphylococcus aureus. In addition, the Photoluminescence properties of the binuclear Zn(II) complex was also investigated.

\section{Experimental Section}

\subsection{Materials and Methods}

Bis 4-carboxyphenyl phenyl phosphine oxide was prepared (Scheme 1) according to the published procedure [22]. All the other chemicals were of reagent grade and were used as commercially obtained without further purification. Elemental analyses (for $\mathrm{C}$ or $\mathrm{H}$ ) were carried out on an Elementar Vario EL III elemental analyzer (Hanau, Germany). PXRD measurements were performed with a Bruker AXS D8 Advance instrument (Karlsruhe, Germany). The FT-IR spectra were recorded in the range $4000-400 \mathrm{~cm}^{-1}$ on a Nicolet 330 FTIR Spectrometer (Nicolet Instrument Inc., Madison, WI, USA) using the $\mathrm{KBr}$ pellet method. TGA experiments were performed using a PerkinElmer TGA 7 instrument (PerkinElmer, Billerica, MA, USA, heating rate of $10^{\circ} \mathrm{C} \mathrm{min}^{-1}$, nitrogen stream).

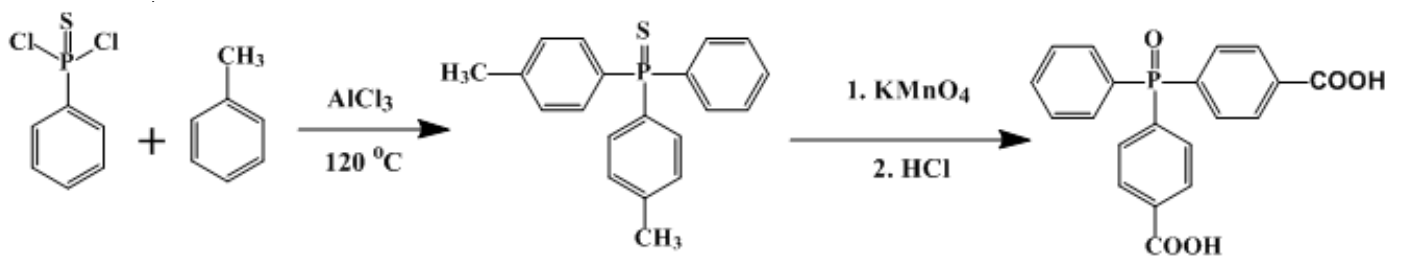

Scheme 1. The synthesis procedure of $\mathrm{H}_{2} \mathrm{BCPPO}$.

\subsection{Synthesis of $\left\{\left[\mathrm{Zn}(\mathrm{BCPPO}) \mathrm{H}_{2} \mathrm{O}\right] \cdot 3 \mathrm{C}_{2} \mathrm{H}_{5} \mathrm{OH}\right\}_{n}(\mathbf{1})$}

A mixture of Bis 4-carboxyphenyl phenyl phosphine oxide $(0.015 \mathrm{mmol}, 5 \mathrm{mg})$ and $\mathrm{Zn}\left(\mathrm{NO}_{3}\right)_{2} \cdot 6 \mathrm{H}_{2} \mathrm{O}(0.10 \mathrm{mmol}, 30 \mathrm{mg})$ were dissolved in $4 \mathrm{~mL}$ of mixed solvents of $\mathrm{DMF} / \mathrm{C}_{2} \mathrm{H}_{5} \mathrm{OH} / \mathrm{H}_{2} \mathrm{O}$ (2:1:1). After ultrasounding at room temperature for $10 \mathrm{~min}$. The glass tube was sealed and placed in an oven and slowly heated to $75^{\circ} \mathrm{C}$ from room temperature in $10 \mathrm{~h}$, kept at $75^{\circ} \mathrm{C}$ for $72 \mathrm{~h}$, and then slowly cooled to $30^{\circ} \mathrm{C}$. Colorless block-shaped crystals suitable for $\mathrm{X}$-ray diffraction analysis were separated by filtration with the yield of $0.029 \mathrm{~g}, 49.6 \%$ (based on zinc). Anal. Calc. (found) for $\mathrm{C}_{26} \mathrm{H}_{33} \mathrm{O}_{9} \mathrm{PZn}: \mathrm{C}, 53.30$ (53.34); H, 5.68 (5.71). IR (KBr): $\mathrm{m}\left(\mathrm{cm}^{-1}\right)=3435(\mathrm{~s}), 1650(\mathrm{~s}), 1556(\mathrm{~s}), 1495(\mathrm{w})$, $1404(\mathrm{~s}), 1167$ (s), $1119(\mathrm{~s}), 1018(\mathrm{~m}), 848(\mathrm{w}), 777(\mathrm{~m}), 734(\mathrm{~s}), 700(\mathrm{~m}), 564(\mathrm{~m}), 501(\mathrm{~m}), 437(\mathrm{~m})$.

\subsection{X-ray Crystallography}

Single crystal of the complex 1 with appropriate dimensions was chosen under an optical microscope and quickly coated with high vacuum grease before being mounted on a glass fiber for data collection. Data were collected on a Bruker Apex II Image Plate single-crystal diffractometer with graphitemonochromated Mo Ka radiation source $\left(\mathrm{k}=0.71073 \mathrm{~A}^{\circ}\right)$ operating at $50 \mathrm{kV}$ and $30 \mathrm{~mA}$ for complex 1. All absorption corrections were applied using the multi-scan program SADABS [23]. In all cases, the highest possible space group was chosen. The structure was solved by direct methods using SHELXS-97 [24] and refined on $\mathrm{F}^{2}$ by full-matrix least-squares procedures with SHELXL-97 [25]. Atoms were located from iterative examination of difference F-maps following least squares refinements of the earlier models. Hydrogen atoms were placed in calculated positions and included as riding atoms with isotropic displacement parameters 1.2 times Ueq of the attached C 
atoms. All structures were examined using the Addsym subroutine of PLATON [26] to assure that no additional symmetry could be applied to the models. The crystallographic details of complex $\mathbf{1}$ are summarized in Table 1. Selected bond lengths and angles for complex $\mathbf{1}$ are collected in Table 2.

Table 1. Crystal data for complex 1.

\begin{tabular}{|c|c|}
\hline Empirical Formula & $\mathrm{C}_{20} \mathrm{H}_{15} \mathrm{O}_{6} \mathrm{PZn}$ \\
\hline Formula weight & 447.66 \\
\hline Temperature (K) & 293(2) \\
\hline Crystal system & monoclinic \\
\hline Space group & $\mathrm{C} 2 / \mathrm{c}$ \\
\hline$a(\AA)$ & $23.5029(6)$ \\
\hline$b(\AA)$ & $10.2695(3)$ \\
\hline$c(\AA)$ & $17.9148(5)$ \\
\hline$\alpha\left(^{\circ}\right)$ & 90 \\
\hline$\beta\left(^{\circ}\right)$ & $100.861(3)$ \\
\hline$\gamma\left({ }^{\circ}\right)$ & 90 \\
\hline Volume $\left(\AA^{3}\right)$ & $4246.52(19)$ \\
\hline Z & 8 \\
\hline$\rho_{\text {calc }}\left(\mathrm{mg} / \mathrm{mm}^{3}\right)$ & 1.400 \\
\hline$\mu\left(\mathrm{mm}^{-1}\right)$ & 1.263 \\
\hline$F(000)$ & 1824.0 \\
\hline Index ranges & $-20 \leq \mathrm{h} \leq 27,-12 \leq \mathrm{k} \leq 12,-21 \leq 1 \leq 20$ \\
\hline Reflections collected & 8476 \\
\hline Independent reflections & $3735[$ Rint $=0.0300$, Rsigma $=0.0442]$ \\
\hline Data/restraints/parameters & $3735 / 0 / 254$ \\
\hline Goodness-of-fit on $\mathrm{F}^{2}$ & 1.072 \\
\hline Final $\mathrm{R}$ indexes $[I \geq 2 \sigma(I)]$ & $R_{1}=0.0436, w R_{2}=0.1190$ \\
\hline Final $\mathrm{R}$ indexes [all data] & $R_{1}=0.0554, w R_{2}=0.1257$ \\
\hline Largest diff. peak/hole $\left(\mathrm{e} \AA^{-3}\right)$ & $0.60 /-0.34$ \\
\hline
\end{tabular}

Table 2. Selected bond lengths $(\AA ̊ ㇒)$ and angles $\left(^{\circ}\right)$ for complex 1.

\begin{tabular}{|c|c|c|c|c|c|}
\hline $\mathrm{Zn} 1-\mathrm{O} 2{ }^{1}$ & $2.038(3)$ & Zn1-O1w & $1.978(3)$ & Zn1-O1 & $2.021(3)$ \\
\hline $\mathrm{Zn} 1-\mathrm{O} 4{ }^{2}$ & $2.035(3)$ & $\mathrm{Zn} 1-\mathrm{O} 3^{3}$ & $2.048(2)$ & $\mathrm{O} 2^{1}-\mathrm{Zn} 1-\mathrm{O} 3^{2}$ & $87.85(13)$ \\
\hline $\mathrm{O} 1 \mathrm{w}-\mathrm{Zn} 1-\mathrm{O} 2{ }^{1}$ & $98.41(13)$ & O1w-Zn1-O1 & $103.08(13)$ & O1w-Zn1-O4 ${ }^{3}$ & $101.13(12)$ \\
\hline $\mathrm{O} 1 \mathrm{w}-\mathrm{Zn} 1-\mathrm{O} 3^{2}$ & $100.73(12)$ & $\mathrm{O} 1-\mathrm{Zn} 1-\mathrm{O} 2^{1}$ & $158.51(13)$ & $\mathrm{O} 1-\mathrm{Zn} 1-\mathrm{O} 4^{3}$ & $87.59(12)$ \\
\hline $\mathrm{O} 1-\mathrm{Zn} 1-\mathrm{O} 3^{2}$ & $87.54(12)$ & $\mathrm{O} 4^{3}-\mathrm{Zn} 1-\mathrm{O} 2^{1}$ & $88.93(12)$ & $\mathrm{O} 4^{3}-\mathrm{Zn} 1-\mathrm{O} 3^{2}$ & $158.15(11)$ \\
\hline
\end{tabular}

Symmetry codes: ${ }^{1} 2-\mathrm{X}, 3-\mathrm{Y}, 1-\mathrm{Z} ;{ }^{2} 1 / 2+\mathrm{X}, 1 / 2+\mathrm{Y},+\mathrm{Z} ;{ }^{3} 3 / 2-\mathrm{X}, 5 / 2-\mathrm{Y}, 1-\mathrm{Z}$.

\subsection{Antibacterial Activity}

The complex was dissolved in N, N-dimethylformamide (DMF) and tested against two reference strains for antibacterial activity, by use of a modified version of the twofold serial dilution method [27] in which the concentration of the complex was repeatedly reduced by half in sterile culture medium containing broth as nutrient. The strains were incubated for $16 \mathrm{~h}$ in culture medium at a constant temperature of $37^{\circ} \mathrm{C}$ after being activated then added to test tubes containing the complex. Readings were taken after incubation for $24 \mathrm{~h}$ at $37^{\circ} \mathrm{C}$. All other test conditions were standardized. Turbidity in all tubes was estimated visually, and the lowest drug concentration inhibiting growth was defined as the minimum inhibitory concentration (MIC). After continuous incubation for $48 \mathrm{~h}$, the minimal bactericidal concentration (MBC) was also defined.

X-ray Powder Diffraction Analyses; IR Spectra; Thermogravimetric Analyse; The solid state photoluminescence spectra of complex 1 and $\mathrm{H}_{2} \mathrm{BCPPO}$ at room temperature. CCDC 1055678 contains the supplementary crystallographic data for this paper. These data can be obtained free of charge from The Cambridge Crystallographic Data Centre via http:/ /www.ccdc.cam.ac.uk/data_request/cif. 


\section{Results and Discussion}

\subsection{Structural Description of $\left\{\left[\mathrm{Zn}(\mathrm{BCPPO}) \mathrm{H}_{2} \mathrm{O}\right] \cdot 3 \mathrm{C}_{2} \mathrm{H}_{5} \mathrm{OH}\right\}_{n}(\mathbf{1})$}

A single-crystal X-ray crystallographic study reveals that the $\mathrm{Zn}(\mathrm{II})$ coordination polymer crystallizes in the space group $C 2 / c$ with $Z$ value of 8 . As can be seen from Figure 1 , complex 1 is a one-dimensional chain consisting of paddle-wheel $\left\{\mathrm{Zn}_{2}(\mathrm{COO})_{4}\right\}$ clusters and BCPPO ligands. The coordination environment of the $\mathrm{Zn}$ (II) ion is shown in Figure 2. The $\mathrm{Zn}$ (II) ion is five-coordinate and displays a typical $\mathrm{ZnO}_{5}$ square-pyramidal coordination geometry. Each $\mathrm{Zn}$ (II) ion bonds to one oxygen donor's atom from one water [Zn1-O1w 1.978(3) $\AA$ ] in the apical position, and four

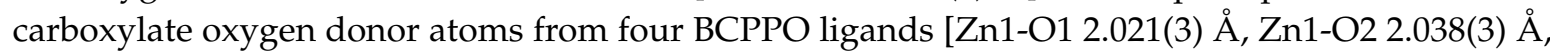

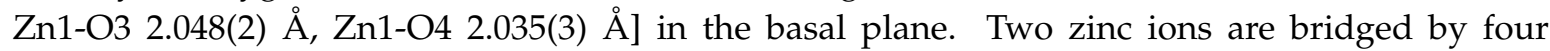
carboxylate groups to form the paddle-wheel binuclear zinc carboxylate clusters $\left\{\mathrm{Zn}_{2}(\mathrm{COO})_{4}\right\}$ with $\mathrm{Zn}-\mathrm{Zn}$ distances of $2.9822(8) \AA$. The $\left\{\mathrm{Zn}_{2}(\mathrm{COO})_{4}\right\}$ clusters are further linked by four BCPPO ligands to create a one-dimensional chain, Figure 1. It is worth pointing out that the tetrahedral geometry at $P$ provides an organic building block that greatly favors the formation of 3-dimensional polymers. However, in complex 1 , the $P=\mathrm{O}$ unit of BCPPO does not coordinate with any $\mathrm{Zn}(\mathrm{II})$ ion, resulting in the formation the one-dimensional chain.

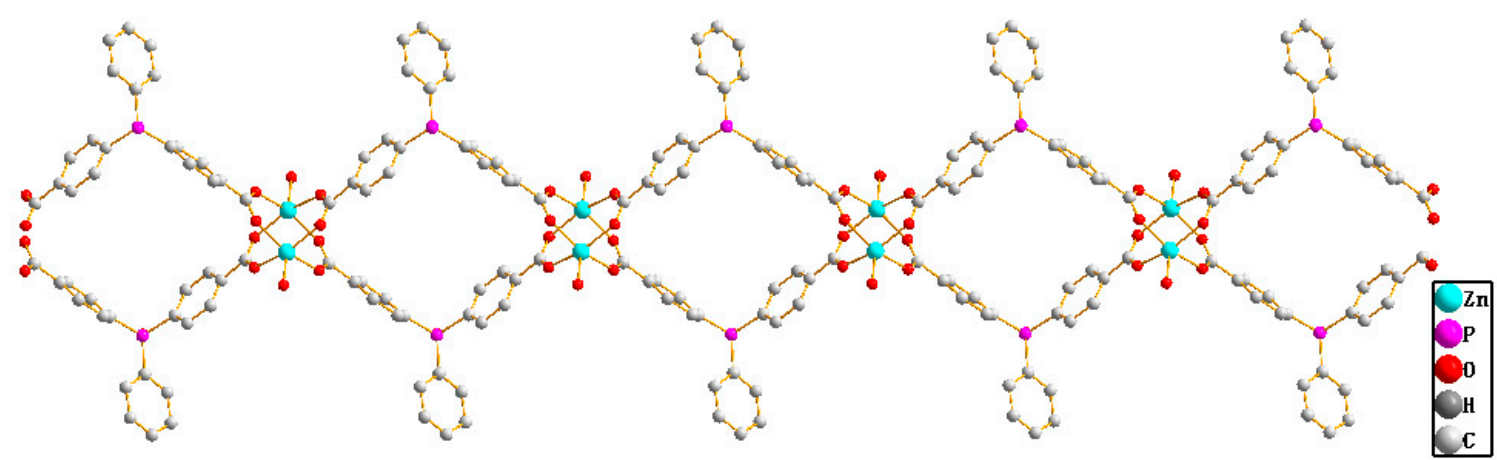

Figure 1. The one-dimensional chain structure of complex 1.

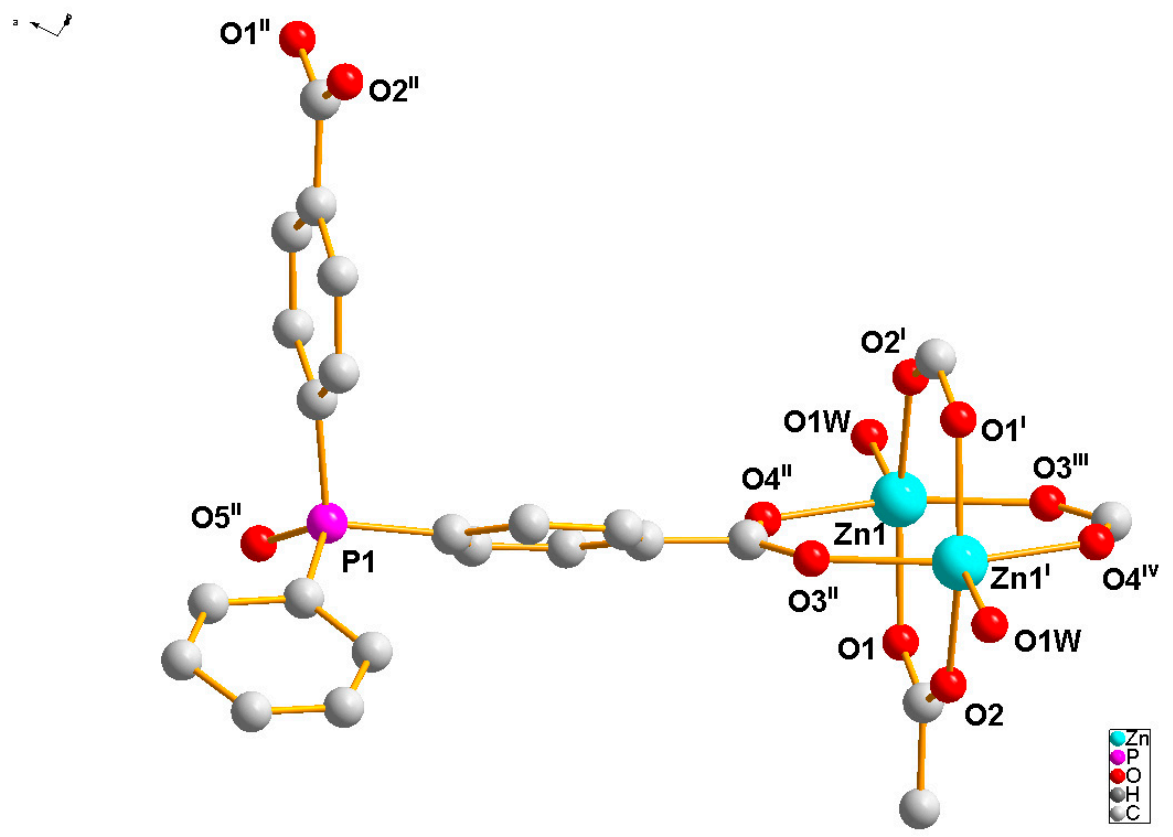

Figure 2. The coordination environment of $\mathrm{Zn}(\mathrm{II})$ center of complex $\mathbf{1}$. 


\subsection{Photoluminescence Properties}

In order to demonstrate the potential application of the complex, the photoluminescence spectra of complex 1 and $\mathrm{H}_{2} \mathrm{BCPPO}$ were investigated in the solid state at room temperature. As shown in Figure S4, the ligand displays emission peak at $429 \mathrm{~nm}$ upon excitation at $396 \mathrm{~nm}$, which can be attributed to the intralig and $\pi^{*}-\pi$ or $\pi-n$ electronic transition. However, the emission peak of complex 1 appears at $447 \mathrm{~nm}$ with $18 \mathrm{~nm}$ of red shift when compared with the $\mathrm{H}_{2} \mathrm{BCPPO}$ ligand, which is probably assigned to a mixture characteristic of intraligand and ligand-to-ligand charge transition as $\mathrm{Zn}(\mathrm{II})$ ion belongs to $\mathrm{d}^{10}$ electronic configurations and is difficult to oxidize or reduce [28].

\subsection{Antibacterial Activity}

In order to explore the potential application of complex $\mathbf{1}$ in an antibacterial situation, the antibacterial activity of the complex $\mathbf{1}$ was assayed against Escherichia coli, and Staphylococcus aureus. The inhibiton zone test graphs of $\mathrm{H}_{2} \mathrm{BCPPO}, \mathrm{DMF}$ and complex 1 against Escherichia coli and Staphylococcus aureus are shown in Figure 3. As can be seen, $\mathrm{H}_{2} \mathrm{BCPPO}$ and DMF did not show antibacterial activity; however, complex 1 had some antibacterial activity to both of the two model bacterial strains, which means that the antibacterial activity has relations with complex 1 . The twofold serial dilution method was employed to further investigate the antibacterial activity of the complex 1 . The results indicated that the minimum bactericidal concentration of complex $\mathbf{1}$ against Escherichia coli, and Staphylococcus aureus is 0.0625 and $0.125 \mathrm{mg} / \mathrm{mL}$, respectively, which are similar to those reported previously for $\mathrm{Zn}$ (II) complexes [29,30]. Therefore, complex $\mathbf{1}$ has potential applications as a broad-spectrum antibacterial agent.
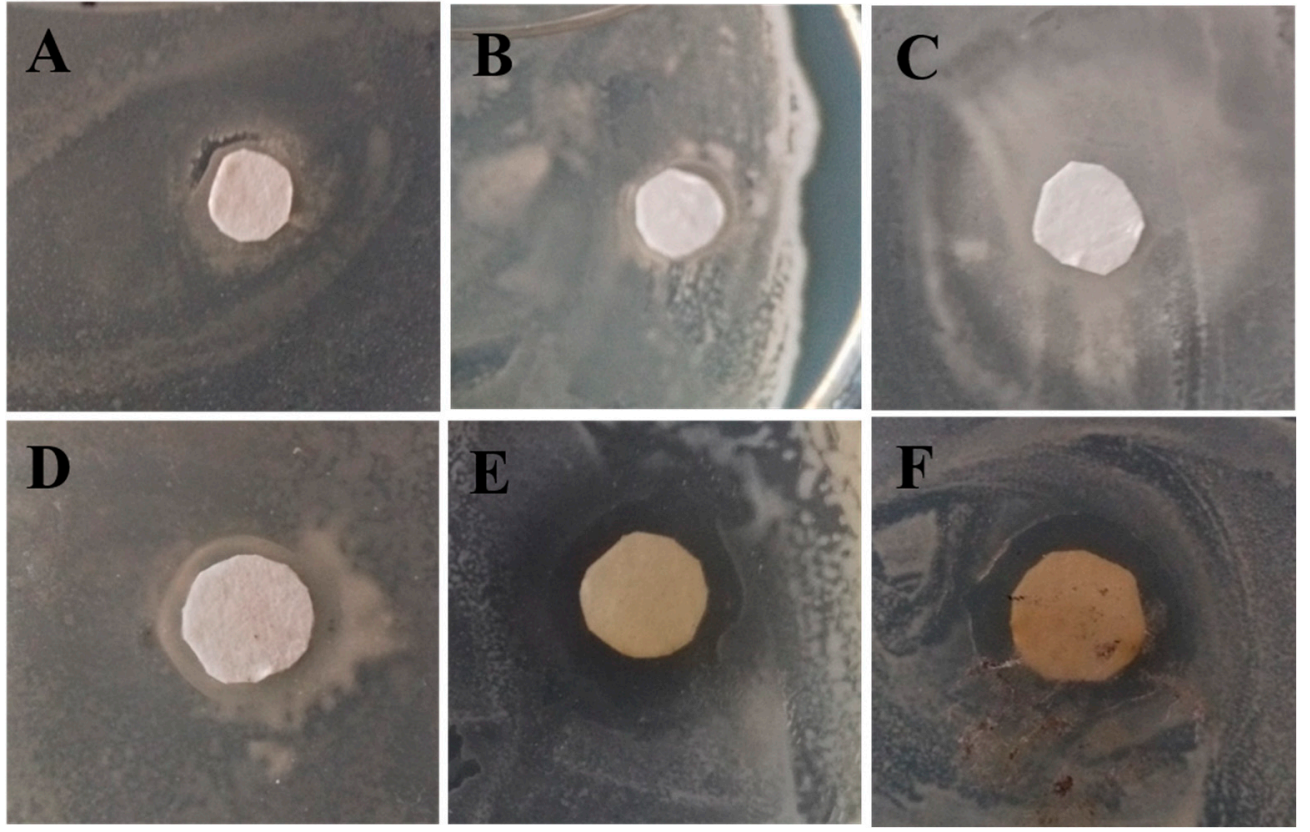

Figure 3. The inhibition zone test graphs of $\mathrm{H}_{2} \mathrm{BCPPO}(\mathbf{A}), \mathrm{N}, \mathrm{N}$-dimethylformamide (DMF) (C), complex 1 (E) against Escherichia coli and $\mathrm{H}_{2} \mathrm{BCPPO}$ (B), DMF (D), comnplex 1 (F) against Staphylococcus aureus, respectively.

\section{Conclusions}

In summary, a dinuclear Zn(II) complex has been synthesized and structurally characterized. As revealed by the single crystal X-ray diffraction, in the dinuclear $\mathrm{Zn}$ (II) complex, two paddle-wheel-type $\mathrm{Zn}_{2}$ units were connected by four BCPPO ligands to form one-dimensional chains. The dinuclear $\mathrm{Zn}(\mathrm{II})$ complex shows excellent and long-term antibacterial activity against 
Escherichia coli and Staphylococcus aureus. In addition, the photoluminescence spectra show that the dinuclear $\mathrm{Zn}(\mathrm{II})$ complex could be useful for a wide range of photochemistry and electroluminescent display applications.

Supplementary Materials: The following are available online at http:/ /www.mdpi.com/2073-4352/7/4/112/s1, Figure S1: The powder XRD patterns and the simulated one from the single-crystal diffraction data for complex 1; Figure S2: FT-IR spectra of complex 1; Figure S3: TG curve of complex 1; Figure S4: The solid state photoluminescence spectra of complex 1 and $\mathrm{H}_{2} \mathrm{BCPPO}$ at room temperature.

Acknowledgments: We gratefully thank the financial support of Shandong Provincial Natural Science Foundation (ZR2015BM005), the NSF of China (Grant No. 21301129), and the China Postdoctoral Science Foundation (2015M572093).

Author Contributions: Jitao Lu and Qingguo Meng conceived and designed the experiments; Dongfang Wang and Chen Yue performed the experiments; Lintong Wang and Jianjian Yang analyzed the data; Jitao Lu wrote the paper.

Conflicts of Interest: The authors declare no conflict of interest.

\section{References}

1. Suh, M.P.; Park, H.J.; Prasad, T.K.; Lim, D.W. Hydrogen Storage in Metal-Organic Frameworks. Chem. Rev. 2012, 112, 782-835. [CrossRef] [PubMed]

2. Zhou, H.C.; Long, J.R.; Yaghi, O.M. Introduction to Metal-Organic Frameworks. Chem. Rev. 2012, 112, 673-674. [CrossRef] [PubMed]

3. Sumida, K.; Rogow, D.L.; Mason, J.A.; McDonald, T.M.; Bloch, E.D.; Herm, Z.R.; Bae, T.H.; Long, J.R. Carbon Dioxide Capture in Metal-Organic Frameworks. Chem. Rev. 2012, 112, 724-781. [CrossRef] [PubMed]

4. Wei, Z.; Gu, Z.-Y.; Arvapally, R.K.; Chen, Y.-P.; McDougald, R.N., Jr.; Lvy, J.F.; Yakovenko, A.A.; Feng, D.; Omary, M.A.; Zhou, H.C. Rigidifying Fluorescent Linkers by Metal-Organic Framework Formation for Fluorescence Blue Shift and Quantum Yield Enhancement. J. Am. Chem. Soc. 2014, 136, 8269-8276. [CrossRef] [PubMed]

5. Trzop, E.; Zhang, D.; Pñiro-Lopez, L.; Valverde-Muñz, F.J.; Muñz, M.C.; Palatinus, L.; Guerin, L.; Cailleau, H.; Real, J.A.; Collet, E. First Step towards a Devil's Staircase in Spin-Crossover Materials. Angew. Chem. Int. Ed. 2016, 55, 8675-8679. [CrossRef] [PubMed]

6. Fei, H.; Shin, J.; Meng, Y.S.; Adelhardt, M.; Sutter, J.; Meyer, K.; Cohen, S.M. Reusable Oxidation Catalysis Using Metal-Monocatecholato Species in a Robust Metal-Organic Framework. J. Am. Chem. Soc. 2014, 136, 4965-4973. [CrossRef] [PubMed]

7. Xue, C.C.; Zhang, H.Y.; Zhang, D.P. Synthesis, Crystal Structure, and Magnetic Characterization of Two Manganese Schiff-Base-Containing Complexes. Russ. J. Coord. Chem. 2017, 43, 260-266.

8. Meng, Q.; Xin, X.; Zhang, L.; Dai, F.; Wang, R.; Sun, D. A multifunctional Eu MOF as a fluorescent pH sensor and exhibiting highly solvent-dependent adsorption and degradation of rhodamine B. J. Mater. Chem. A 2015, 3, 24016-24021. [CrossRef]

9. Zhu, Q.L.; Xu, Q. Metal-organic framework composites. Chem. Soc. Rev. 2014, 43, 5468-5512. [CrossRef] [PubMed]

10. Shi, J.; Xue, C.; Kong, L.; Zhang, D. Three 1D cyanide-bridged M(Ni, Pd, Pt)-Mn(II) coordination polymer: Synthesis, crystal structure and magnetic properties. Acta Chim. Slov. 2017, 64, 215-220. [PubMed]

11. Sun, D.; Yan, Z.; Liu, M.; Xie, H.; Yuan, S.; Lu, H.; Feng, S.; Sun, D. Three- and Eight-Fold Interpenetrated $\mathrm{ThSi}_{2}$ Metal-Organic Frameworks Fine-Tuned by the Length of Ligand. Cryst. Growth Des. 2012, 12, 2902-2907. [CrossRef]

12. Sun, D.; Xu, H.; Yang, C.; Wei, Z.; Zhang, N.; Huang, R.; Zheng, L. Encapsulated Diverse Water Aggregates in Two Ag(I)/4,4'-Bipyridine/Dicarboxylate Hosts: 1D Water Tape and Chain. Cryst. Growth Des. 2010, 10, 4642-4649. [CrossRef]

13. Wang, S.; Xiong, S.; Wang, Z.; Du, J. Rational Design of Zinc-Organic Coordination Polymers Directed by N-Donor Co-ligands. Chem. Eur. J. 2011, 17, 8630-8642. [CrossRef] [PubMed]

14. Zhang, L.; Kang, Z.; Xin, X.; Sun, D. Metal-organic frameworks based luminescent materials for nitroaromatics sensing. CrystEngComm 2016, 18, 193-206. [CrossRef] 
15. Rao, X.; Song, T.; Gao, J.; Cui, Y.; Yang, Y.; Wu, C.; Chen, B.; Qian, G. A highly sensitive mixed lanthanide metal-organic framework self-calibrated luminescent thermometer. J. Am. Chem. Soc. 2013, 135, 15559-15564. [CrossRef] [PubMed]

16. Zang, S.; Cao, L.; Liang, R.; Hou, H.; Mak, T. Divalent Zinc, Cobalt, and Cadmium Coordination Polymers of a New Flexible Trifunctional Ligand: Syntheses, Crystal Structures, and Properties. Cryst. Growth Des. 2012, 12, 1830-1837. [CrossRef]

17. Niu, D.; Yang, J.; Guo, J.; Kan, W.; Song, S.; Du, P.; Ma, J. Syntheses, Structures, and Photoluminescent Properties of 12 New Metal-Organic Frameworks Constructed by a Flexible Dicarboxylate and Various N-Donor Ligands. Cryst. Growth Des. 2012, 12, 2397-2410. [CrossRef]

18. Tai, X.; Jie, Y. Synthesis, Crystal Structure and Antibacterial Activity of $\mathrm{Mg}$ (II) Complex $\left[\mathrm{Mg}\left(\mathrm{H}_{2} \mathrm{O}\right)_{6}\right] \cdot(4 \text {-amino-3-methylbenzenesulfonate })_{2}$. Crystals 2015, 5, 294-301. [CrossRef]

19. Tai, X.; Zhao, W. Synthesis, crystal structure, and antibacterial activity of magnesium (II) coordination polymers formed by hydrogen bonding. Res. Chem. Intermed. 2015, 41, 3471-3478. [CrossRef]

20. Ali, H.; Omar, S.N.; Drawsheh, M.D.; Fares, H. Synthesis, characterization and antimicrobial activity of zinc (II) ibuprofen complexes with nitrogen-based ligands. J. Coord. Chem. 2016, 69, 1110-1122. [CrossRef]

21. Jinu, U.; Gomathi, M.; Saiqa, I.; Geetha, N.; Benelli, G.; Venkatachalam, P. Green engineered biomolecule-capped silver and copper nanohybrids using Prosopis cineraria leaf extract: Enhanced antibacterial activity against microbial pathogens of public health relevance and cytotoxicity on human breast cancer cells (MCF-7). Microb. Pathog. 2017, 105, 86-95. [CrossRef] [PubMed]

22. Morgan, P.W.; Herr, B.C. Some dicarboxylic acids and esters containing the phosphine oxide group. J. Am. Chem. Soc. 1952, 74, 4526-4529. [CrossRef]

23. Bruker, S.M.A.R.T. SAINT and SADABS; Bruker AXS Inc.: Madison, WI, USA, 1998.

24. Sheldrick, G.M. SHELXS-97, Program for X-ray Crystal Structure Determination; University of Gottingen: Gottingen, Germany, 1997.

25. Sheldrick, G.M. SHELXL-97, Program for X-ray Crystal Structure Refinement; University of Gottingen: Gottingen, Germany, 1997.

26. Spek, A.L. PLATON, A Multipurpose Crystallographic Tool; Utrecht University: Utrecht, The Netherlands, 2002.

27. Zheng, J.Y.; Wang, G.B. Medicines and Chemical Reagents Microbiology and Assay Technology; People's Health Press: Beijing, China, 1989.

28. Allendorf, M.D.; Bauer, C.A.; Bhaktaa, R.K.; Houka, R.J.T. Luminescent metal-organic frameworks. Chem. Soc. Rev. 2009, 38, 1330-1332. [CrossRef] [PubMed]

29. Keypour, H.; Mahmoudabadi, M.; Shooshtari, A. Synthesis of Mn(II) and Zn(II) complexes with new macrocyclic Schiff-base ligands containing piperazine moiety: Spectroscopic, structural, cytotoxic and antibacterial properties. Polyheron 2017, 127, 345-354. [CrossRef]

30. Grabchev, I.; Yordanova, S.; Bosch, P.; Vasileva-Tonkov, E.; Kukeva, R.; Stoyanov, S.; Stoyanova, R. Structural characterization of 1,8-naphthalimides and in vitro microbiological activity of their $\mathrm{Cu}$ (II) and $\mathrm{Zn}$ (II) complexes. J. Mol. Struct. 2017, 1130, 974-983. [CrossRef]

(c) 2017 by the authors. Licensee MDPI, Basel, Switzerland. This article is an open access article distributed under the terms and conditions of the Creative Commons Attribution (CC BY) license (http:/ / creativecommons.org/licenses/by/4.0/). 